\title{
Productive and Reproductive Traits of Sheep Fed Acacia saligna Leaves-Based Diets
}

\author{
Sobhy M.A. Sallam ${ }^{1}$, Mohamed N. El-Gendy ${ }^{2}$, Mohamed M. Anwar ${ }^{2}$, Wael G. Fahmy ${ }^{1}$, \\ Samir Z. El-Zarkouny ${ }^{1,3}$, Nesrin M. Hashem ${ }^{1}$, Adel N. M. Nour El-Din ${ }^{1}$, Marwa F.A. \\ Attia $^{1}$, El-Saeed A. El-wakeel ${ }^{2}$, Moustafa M. Zeitoun ${ }^{1, *}$
}
${ }^{1}$ Department of Animal and Fish and Production, Faculty of Agriculture, University of Alexandria, Egypt. ${ }^{2}$ Animal Production Research Institute, Agricultural Research Center, Dokki, Giza, Egypt.
${ }^{3}$ Department of Arid Land Agriculture, Faculty of Meteorology, Environment and Arid Land Agriculture, KAU, KSA *Corresponding author: Prof; Moustafa M. Zeitoun; email: mmzeitoun@ yahoo.com; mobile: +96655994033; fax: $+966163801360$

\begin{abstract}
Investigating effects of partial (50\%) or total (100\%) substitution of clover hay by tannins-rich plant (Acacia saligna) on productive and reproductive performance of ewe lambs was the main goal of this study. Two experiments were conducted: first focusing on digestibility and $N$ balance using 9 Barky rams (live body weight, $43 \pm 2.5 \mathrm{~kg}$ ) where animals were randomly divided into 3 groups $(n=3)$; control $(C), 50 \%$ Acacia $\left(A S_{50 \%}\right)$ and $100 \%$ Acacia $\left(A S_{100 \%}\right) ;$ second focusing on productive and reproductive performance of ewe-lambs $(n=18)$ where animals were divided into three groups (n=6); $C, A S_{50 \%}$ and $A S_{100 \%}$. This experiment started 2 months before mating and continued till weaning. Dry matter intake decreased $(P<0.05)$ linearly due with treatment. The digestion coefficients of dry matter (DM), organic matter $(O M)$, crude protein $(C P)$, neutral detergent fiber $(N D F)$ and acid detergent fiber $(A D F)$ were lower $(P<0.05)$ in treated than $C$. The nitrogen intake and urinary nitrogen were reduced $(P<0.05)$ by treatment, while fecal nitrogen increased $(P<0.0 \%)$ with treatment. No change was found in conception rates among the three groups whereas fertility rates and lambing rates were higher in the treated compared to the control. AS $100 \%$ reduced $(P<0.05)$ total protein and blood urea nitrogen (BUN) compared to other groups. No differences in progesterone concentration were found among groups. AS $50 \%$ resulted in higher $(P<0.05)$ milk yield than other groups. Treatment decreased $(P<0.05)$ milk fat percentage, whereas didn't change protein and lactose. Therefore, partial replacement of acacia leaves in sheep diets could be beneficial for productive and reproductive performance.
\end{abstract}

Keywords- Feed additives, digestibility, rumen fermentation, blood metabolites, prolificacy.

\section{INTRODUCTION}

The major limitation to ruminant's production in many tropical regions is poor nutrition, which is characterized by low nitrogen and high fiber content in native grasses and crop residues. In Egypt, the primary constraints to livestock production are scarcity and fluctuating quantity and quality of the year-round feed supply. The gap between available and required amounts of animal feedstuffs in Egypt was estimated to be 3.5 million tons. There are two alternative strategies to overcome the problem of feeds shortage in Egypt. The first is to maximize utilization of agricultural and industrial byproducts and there are several studies focused on this point. The second strategy is seeking alternative nonconventional feed resources e.g. tannins-rich plants or shrub legumes, which have high protein contents and are potentially promising to overcome nutrient deficiencies.

The multipurpose trees and tannins-rich plants represent an important fodder reserve for ruminants in periods of feed scarcity and play vital role in bridging the wide gap between supply and demand of feeds [1]. Use of these forages in animal diets may participate in reducing the shortage of animal feed resources, enhance the fertility performance of animals and subsequently increase milk and meat production in tropic regions. The shrub foliages already play an important role in ruminant feeding systems in Mediterranean and many tropical environments around the world [2-5].

To efficiently use alternative feed resources like tanninsrich plants, their effects on various aspects need to be considered. This needs more research to be done for fair judgment within different points of view. Therefore, the objectives of this study were to assess effects of the partial or total replacement of clover hay by acacia leaves as an alternative feed resource on the dry matter intake, nutrients utilization, ruminal fermentation profiles, reproductive and productive performance of Barky sheep.

\section{MATERIAL AND METHODS}

This study was carried out at the Nubaria Research Station, Animal Production Research Institute, Agricultural Research Center, Ministry of Agriculture and Land Reclamation, Dokki, (Exp.1) and the Research Farm 
of the Department of Animal and Fish Production, Faculty of Agriculture, University of Alexandria (Exp. 2), Egypt. Two experiments were designed to investigate the potential replacement of clover (Trifolium alexandrina) hay by acacia (Acacia saligna, AS) leaves either partially $\left(50 \%, \mathrm{AS}_{50 \%}\right)$ or totally $\left(100 \%, \mathrm{AS}_{100 \%}\right)$. First experiment was designed to investigate digestibilty and nitrogen balance trial. However, the second experiment focused on the productive and reproductive performance of ewelambs.

\begin{abstract}
Acacia samples collection
Acacia leaves were collected weekly during both experimental periods in order to offer as fresh materials for animals. Extra samples of acacia leaves were collected monthly during a year to analyze total phenols (TP), total tannins (TT) and condensed tannin (CT). The collection region was located at latitude of 30.91 and longitude: 29.68 . The region climate was semi-arid Mediterranean climate, which is characterized by a brief mild and rainy winter and long warm summer months with no rain. The chemical composition and tannins content of the commercial concentrate mixture, clover hay and acacia leaves for both experiments are presented in Table 1.
\end{abstract}

Table.1: Chemical composition and tannins content of the concentrate mixture, clover hay and Acacia leaves (Based on dry matter)

\begin{tabular}{lccc}
\hline Item $(\%)$ & Concentrate & Clover hay & Acacia leaves \\
\hline OM & 88.5 & 89.3 & 89.6 \\
CP & 14.1 & 12.5 & 13.2 \\
EE & 5.8 & 1.0 & 4.8 \\
NDF & 38.3 & 64.2 & 64.9 \\
ADF & 10.6 & 55.8 & 60.6 \\
\hline Tannins content & & & \\
\hline TP* & - & 10.2 & 42.1 \\
TT* & - & 1.6 & 27.1 \\
CT $^{* *}$ & - & 2.0 & 72.0 \\
\hline
\end{tabular}

OM: Organic matter, CP: Crude protein, EE: Ether extract, NDF: Neutral detergent fiber, ADF: Acid detergent fiber. *TP: total phenols (eq-g tannic acid kg-1 DM), *TT: total tannins (eq-g tannic acid $\mathrm{kg}^{-1} \mathrm{DM}$ ), **CT: condensed tannins (eq-g leucocyanidin $\mathrm{kg}^{-1} \mathrm{DM}$ ).

\section{Experiment 1}

\section{Animals and experimental design}

Nine mature Barky rams (mean live body weight $43 \pm 2.5$ $\mathrm{kg}$ ) were randomly divided into three equal groups $(\mathrm{n}=3)$ as control (C), $\mathrm{AS}_{50 \%}$ and $\mathrm{AS}_{100 \%}$ according to live body weight. Animals were housed in well-ventilated shade and adapted to the treatment feeds for 4 weeks before being subjected to the digestibility trial and had free access to fresh water. The animals were fed in groups on a commercial concentrate feed mixture and roughages according to NRC [6]. The acacia leaves were offered fresh daily as partial or total replacement to the clover hay by $1.0 \mathrm{~kg}$ and $2.0 \mathrm{~kg} / \mathrm{h} / \mathrm{d}$, respectively, while the clover hay was offered to the control and partial replacement group by 1.0 and $0.5 \mathrm{~kg} / \mathrm{h} / \mathrm{d}$, respectively. The commercial concentrate feed mixture was offered to all groups by 0.75 $\mathrm{kg} / \mathrm{h} / \mathrm{d}$ for all groups. After familiarization to the diets, the animals were kept in metabolic cages for 8 days of which 3 days for adaptation and 5 days for samples collection. Experimental animals were offered concentrate and roughages individually in buckets twice daily at 8:00 and 14:00 hr. During the collection period, animals were individually kept in metabolic cages and feed refusals, feces and urine were collected for the purpose of measuring nutrients digestibility and $\mathrm{N}$ balance.

To measure apparent total tract nutrients digestibility, two representative samples of feces $10 \%$ of the total quantity) were collected daily from each animal; one of the two samples was sprayed with citric acid (10\%) and stored under $-20^{\circ} \mathrm{C}$, the second was used for determination of the feces DM. Immediately, at the end of collection period stored feces samples during 5 days for each animal were pooled, mixed well and a sample was obtained for further analyses. Representative portions of feces were dried in a forced air-oven at $50^{\circ} \mathrm{C}$ for $48 \mathrm{~h}$ and then ground to pass through a $1 \mathrm{~mm}$-screen and stored at $-20^{\circ} \mathrm{C}$ thereafter until analysis.

The urine was collected daily throughout the collection period in plastic buckets containing $100 \mathrm{~mL}$ of $\mathrm{H}_{2} \mathrm{SO}_{4}$ $(10 \%)$. Also, representative samples $(10 \%$ of total volume) were collected daily from each animal and kept in dark bottles. At the end of collection period, urine samples from each animal were mixed well and obtained a sample, which kept under $-20^{\circ} \mathrm{C}$ until analysis. Upon 
analysis, thawed urine samples were centrifuged at 2000 rpm for $20 \mathrm{~min}$ and sub-samples were analyzed for Kjeldahl N [7]. Ruminal fluid samples were obtained from each animal via a stomach tube before morning feeding for two consecutive days. The ruminal fluid samples were separated from the feed particles through four layers of cloth sheets and then stored under $-20^{\circ} \mathrm{C}$ for VFA and ammonia $\mathrm{N}$ analyses.

\section{Experiment 2}

\section{Animals and experimental design}

Eighteen ewe-lambs (live body weight of $35 \pm 2.5 \mathrm{~kg}$ and age of 10 months) were divided into three equal groups $(n=6)$ according to the body weight; control (C), $\mathrm{AS}_{50 \%}$ and $\mathrm{AS}_{100 \%}$ to study the reproductive and productive performance. Ewe-lambs were fed on a commercial concentrate feed mixture, clover hay and acacia leaves according to NRC [6]. The acacia leaves were collected and offered fresh daily. The Alexandria University guideline for the ethics and use of experimental animals was approved.

\section{Reproductive performance of ewe-lambs}

This study was started two months before mating and continued till lambing. The control ewe-lambs were fed on a commercial concentrates feed mixture and clover hay $(1.0 \mathrm{~kg} / \mathrm{h} / \mathrm{d})$. The $\mathrm{AS}_{50 \%}$ animals were fed a commercial concentrate feed mixture and clover hay $(0.5 \mathrm{~kg} / \mathrm{h} / \mathrm{d})$ and acacia leaves $(1.0 \mathrm{~kg} / \mathrm{h} / \mathrm{d})$. The $\mathrm{AS}_{100 \%}$ animals were fed a commercial concentrate feed mixture and acacia leaves $(2.0 \mathrm{~kg} / \mathrm{h} / \mathrm{d})$.

Ewe-lambs were fed the commercial concentrate mixture in groups, hay and acacia leaves in about two equal parts at 8:00 and 14:00 hr daily. The ewe-lambs had free access to fresh water through the experimental period. Blood samples were collected every month from the jugular vein, before access to feed and water in test tube without anti-coagulant. The samples were centrifuged at $3000 \mathrm{rpm}$ for $20 \mathrm{~min}$ to get the serum for biochemical parameters assay. Total protein and albumin were assayed by colorimetric kits (Stanbio, Boerne, Texas, USA). Glucose was assayed using colorimetric kits (Futura System, Formello, Rome, Italy) and blood urea nitrogen (BUN), creatinine and cholesterol were assayed by colorimetric kits (BioSystems, Costa Brava, Barcelona, Spain). Globulin concentration was calculated as the difference between total protein and albumin.

After two months of the beginning of the experiment, all ewe-lambs were injected with prostaglandin $\mathrm{PGF}_{2 \alpha}(0.5$ $\mathrm{ml}$ of estroPLAN with the concentration of $125 \mu \mathrm{g}$ Cloprostenol; Parnell Technologies, Alexandria, New South Wales, Australia). The animals were submitted to estrus detection twice daily using mature teaser ram at 7.00 and $19.00 \mathrm{hr}$ for 3 days, ewe-lambs which were mounted by teaser rams, were mated by fertile rams. The ewe-lambs which was insensitive to the effects of first $\mathrm{PGF}_{2 \alpha}$ received a second injection of $\mathrm{PGF}_{2 \alpha}(0.5 \mathrm{ml}$ of estroPLAN with the concentration of $125 \mu \mathrm{g}$ Cloprostenol) after 12 days from the first injection then submitted to estrus detection twice daily using mature teaser ram at 7.00 and $19.00 \mathrm{hr}$ for 3 days. Ewe-lambs which were mounted by teaser rams were mated by fertile rams. A blood sample was taken from each ewe-lamb at the days of injection, estrus, 5, 10 and 20 after estrus for determination of BUN and progesterone.

\section{Productive performance of ewes}

Birth weight of the neonates were recorded at the day of birth and their weaning weights were recorded when lambs reached the age of 4 months. Daily weight gain of lambs was calculated using weekly body weight for each lamb.

Milk production was measured weekly postpartum and for seventeen weeks (119 day). Daily milk yield for each ewe was performed using weigh suckle-weigh technique [8]. Lambs were separated from their dams at 14:00 hr the day before milking and in the day after. The lambs were weighed at 6:00 $\mathrm{hr}$ and left to suckle their dams till satisfactions. They were weighed again and kept in closed pens till next milking at 14:00 hr. In the meantime their dams were striped to estimate the stripping milk. The same procedure was followed again at 14:00 $\mathrm{hr}$ in the same day. The daily milk yield was calculated by summing the weight of suckled milk (differences between lamb's weight before and after suckling) and the weight of striped milk in both morning and afternoon milking. Milk production was evaluated using a graduated cylinder $( \pm 5$ $\mathrm{mL}$ ). The amount of milk obtained was adjusted for $24 \mathrm{hr}$ on weekly basis. Milk samples $(100 \mathrm{~mL})$ from individual ewes were taken for proximate analysis using Milk Analyzer (Milko Tester Instruments Inc., Bulgaria).

Milk urea nitrogen (MUN) was determined by adding 2 $\mathrm{mL}$ trichloroacetic acid $(10 \%)$ to $5 \mathrm{~mL}$ of milk sample for protein precipitation and left for $30 \mathrm{~min}$ then the mixture was centrifuged at $3000 \mathrm{rpm}$ for $20 \mathrm{~min}$ in order to separate the supernatant which was used to determine milk urea nitrogen by colorimetric method (Stanbio, Boerne, Texas, USA) [7].

Blood samples were collected every month until the end of the experiment from the jugular vein, before access to feed and water in test tube without anti-coagulant to get coagulated blood samples. The samples were centrifuged at $3000 \mathrm{rpm}$ for $20 \mathrm{~min}$ and sera were harvested for biochemical assays.

\section{Samples analysis}

The dry matter (DM) of feed and feces were analyzed by drying at $105^{\circ} \mathrm{C}$ for $24 \mathrm{~h}$. The AOAC (2006) analytical procedures were used for the organic matter (OM) 
determination (No. 968.08) by ashing at $600{ }^{\circ} \mathrm{C}$ for $2 \mathrm{~h}, \mathrm{~N}$ estimation (No. 988.05) by a Kjeldahl technique and ether extract. Neutral detergent fiber (NDF) and acid detergent fiber (ADF) were determined according to the procedure of Van Soest et al. [9] without sodium sulfite or $\alpha$ amylase and expressed with residual ash. Concentrations of $\mathrm{NH}_{3} \mathrm{~N}$ and total volatile fatty acid (VFA) were determined according to Preston [10] and Warner [11], respectively.

Total phenols (TP) were determined with the FolinCiocalteau reagent according to Makkar [12]. Total tannins (TT) were determined as the difference in TP before and after treatment with insoluble polyvinyl polypyrrolidone (PVPP) [13]. Condensed tannins (CT) were measured by the $\mathrm{HCl}$ - butanol method according to Makkar (2003). TP and TT were expressed as tannic acid equivalents and condensed tannins were expressed as leucocyanidin equivalent [12].

\section{Statistical analysis}

First experiment data were subjected to analysis of variance (ANOVA) using the general linear model procedure (GLM) of SAS software package [14]. The used model was: $Y_{i j}=\mu+F_{i}+e_{i j}$ where: $\mu$ is the overall mean, $F_{i}$ is the treatment effect, $e_{i j}$ is the random error term. The significant differences between individual means were identified by using Tukey test.
Second experiment data were analyzed using GLM of SAS [14]. The model included effect of treatment, time, and their interaction on different variables that were tested in a repeated measurement design as follows: $Y_{i j k}=\mu+T_{i}$ $+P_{j}+(T P)_{i j}+A_{k t}+e_{i j k}$; Where: $\mu$ is overall mean, $T i$ is a fixed effect of the treatment ( $\mathrm{i}=1$ to 2 ), $\mathrm{Pj}$ is a fixed effect of the time ( $\mathrm{j}=1$ to 8$), \mathrm{TP}_{\mathrm{ij}}$ is an interaction between treatment and time, $A_{k t}$ is random effect of the animal (within treatment) and $\mathrm{e}_{\mathrm{ijk}}$ is random error assumed to be independent by and normally distributed with mean $=0$ and variance $=\sigma 2$. The reproductive traits results were compared among studied groups using Chi-square.

\section{RESULTS}

\section{Experiment 1.}

Data of the effect of partial $(50 \%)$ and total (100\%) replacements of clover hay by acacia leaves on dry matter intake (DMI) and apparent total tract nutrient digestibility of Barky sheep are shown in Table (2). There was a linear reduction $(\mathrm{P}<0.01)$ in DMI by increasing acacia leaves compared to the control. Percentages of reductions in DMI due to partial (50) and total (100\%) replacement by acacia leaves were 9.2 and $28.5 \%$, respectively compared to the control. The apparent total tract digestion coefficients of dry matter (DM), organic matter (OM), crude protein (CP), natural detergent fiber (NDF) and acid detergent fiber $(\mathrm{ADF})$ were significantly lower $(\mathrm{P}<0.01)$ in treated than control animals.

Table.2: Effect of partial and total replacement of clover hay by acacia leaves on apparent total tract nutrients digestibility in Barky ewe lambs

\begin{tabular}{|c|c|c|c|c|}
\hline \multirow{2}{*}{ Item } & \multirow{2}{*}{ Control } & \multicolumn{2}{|c|}{ Acacia } & \multirow[b]{2}{*}{$P$ Value } \\
\hline & & $\mathrm{AS}_{50 \%}$ & $\mathrm{AS}_{100 \%}$ & \\
\hline \multicolumn{5}{|l|}{ Intake $(\mathrm{g} / \mathrm{h} / \mathrm{d})$} \\
\hline Clover hay & $900.2 \pm 5.6$ & $454.6 \pm 5.6$ & 0 & - \\
\hline Acacia leaves & 0 & $314.7 \pm 20.5$ & $462.8 \pm 25.1$ & - \\
\hline $\mathrm{CFM}$ & $634.1 \pm 6.9$ & $622.8 \pm 6.9$ & $634.1 \pm 8.5$ & - \\
\hline DMI g/d & $1534.3 \pm 21.1^{\mathrm{a}}$ & $1392.2 \pm 21.1^{\mathrm{b}}$ & $1096.9 \pm 25.9^{c}$ & $<0.0001$ \\
\hline \multicolumn{5}{|c|}{ Digestion coefficient (\%) } \\
\hline DM & $72.2 \pm 1.3^{\mathrm{a}}$ & $67.0 \pm 1.3^{\mathrm{b}}$ & $57.3 \pm 1.6^{\mathrm{c}}$ & $<0.0001$ \\
\hline OM & $74.0 \pm 1.2^{\mathrm{a}}$ & $69.7 \pm 1.2^{\mathrm{b}}$ & $60.3 \pm 1.5^{\mathrm{c}}$ & $<0.0001$ \\
\hline $\mathrm{CP}$ & $68.9 \pm 1.6^{\mathrm{a}}$ & $55.7 \pm 1.6^{\mathrm{b}}$ & $38.0 \pm 2.0^{c}$ & $<0.0001$ \\
\hline $\mathrm{NDF}$ & $73.0 \pm 1.5^{\mathrm{a}}$ & $65.8 \pm 1.5^{\mathrm{b}}$ & $52.6 \pm 1.9^{c}$ & $<0.0001$ \\
\hline $\mathrm{ADF}$ & $68.8 \pm 2.5^{\mathrm{a}}$ & $57.8 \pm 2.5^{\mathrm{b}}$ & $35.5 \pm 3.0^{c}$ & $<0.0001$ \\
\hline
\end{tabular}

Means in the same row with different superscripts significantly differ $(P<0.05)$.

CFM : Concentrate feed mixture; DMI : Dry matter intake; DM : Dry matter; OM : Organic matter; CP :Crude protein; $\mathrm{EE}$ :Ether extract; $\mathrm{CF}$ :Crude fiber; NDF : Neutral detergent fiber; ADF : Acid detergent fiber.

Table (3) presents data of the effects of acacia leaves replacement on nitrogen utilization, rumen $\mathrm{NH}_{3}-\mathrm{N}$ and VFA concentration of Barky sheep. There were linear $(\mathrm{P}<0.01)$ reductions in both nitrogen intake $(\mathrm{NI})$ and urinary nitrogen due to replacement compared to control. In contrast, the fecal nitrogen increased $(P<0.01)$ up to
$48 \%$ with acacia replacement. Significant reductions $(P<0.01)$ in nitrogen balance were found in animals given partial $(26 \%)$ and total $(79.9 \%)$ acacia leaves compared with control. There were no significant differences in the concentrations of VFA and ammonia due to acacia replacement. 
Table.3: Effect of partial and total replacement of clover hay by acacia leaves on nitrogen utilization, rumen $\mathrm{NH}_{3}-\mathrm{N}$ and VFA concentration in Barky sheep

\begin{tabular}{|c|c|c|c|c|}
\hline \multirow{2}{*}{ Item, g/d } & \multirow{2}{*}{ Control } & \multicolumn{2}{|c|}{ Acacia } & \multirow{2}{*}{$P$ Value } \\
\hline & & $\mathrm{AS}_{50 \%}$ & $\mathrm{AS}_{100 \%}$ & \\
\hline $\mathrm{N}$ intake & $32.30 \pm 0.26^{\mathrm{a}}$ & $29.83 \pm 0.26^{\mathrm{b}}$ & $24.10 \pm 0.26^{c}$ & $<0.0001$ \\
\hline Fecal N & $10.01 \pm 0.72^{\mathrm{b}}$ & $13.14 \pm 0.72^{\mathrm{a}}$ & $14.85 \pm 0.72^{\mathrm{a}}$ & 0.0086 \\
\hline Urinary $\mathrm{N}$ & $9.90 \pm 0.76^{\mathrm{a}}$ & $7.52 \pm 0.76^{\mathrm{ab}}$ & $6.74 \pm 0.76^{\mathrm{b}}$ & 0.0597 \\
\hline Nitrogen balance & $12.39 \pm 0.51^{\mathrm{a}}$ & $9.17 \pm 0.51^{b}$ & $2.51 \pm 0.51^{\mathrm{c}}$ & $<0.0001$ \\
\hline VFA (meq/dl) & $8.68 \pm 0.75$ & $8.52 \pm 0.75$ & $7.13 \pm 0.75$ & 0.3066 \\
\hline $\mathrm{NH}_{3}-\mathrm{N}(\mathrm{mg} / \mathrm{dl})$ & $14.35 \pm 0.64$ & $13.06 \pm 0.78$ & $13.41 \pm 0.64$ & 0.4131 \\
\hline
\end{tabular}

Means in the same row with different superscripts significantly differ $(P<0.05)$.

VFA: Volatile fatty acids

\section{Experiment 2.}

The chemical composition of the total phenols (TP), total tannins (TT) and condensed tannins (CT) of acacia leaves throughout the experimental period is presented in Figure 1.

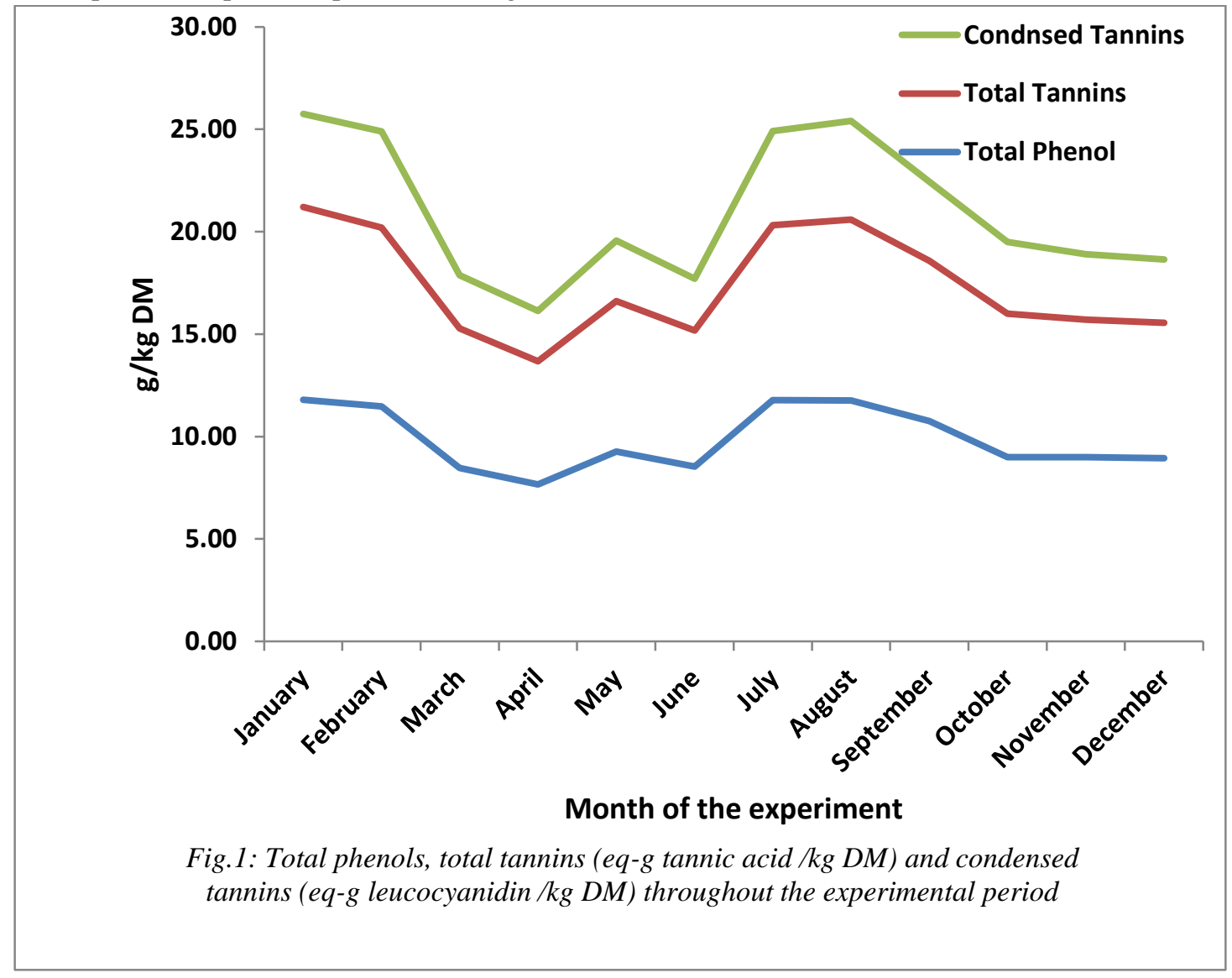

The phenolic compounds like TP, TT and CT concentrations exhibited similar trends throughout the entire experimental period. They tended to decrease gradually from February till June then increased slightly again to reach peaks in August and decreased thereafter till December. Mean values of TP, TT and CT in acacia leaves were $100.4 \mathrm{~g}$ tannic acid $\mathrm{kg}^{-1} \mathrm{DM}, 76.8 \mathrm{~g}$ tannic acid $\mathrm{kg}^{-1} \mathrm{DM}$ and $36.1 \mathrm{~g}$ leucocyanidin $\mathrm{kg}^{-1} \mathrm{DM}$, respectively.
Table 4 shows data of the effects of partial and total replacement of clover hay by acacia leaves on ewe's reproductive parameters. Results showed that number services per conception were similar (1.17) among groups. Likewise, conception rate have similar percentage among groups, while fertility rate and lambing rate were less in control than treated animals. The replacement of acacia leaves has no significant effect on litter size. 
Table.4: Effect of partial and total replacement of clover hay by acacia leaves on some reproduction traits of Barky ewes

\begin{tabular}{lccc}
\hline \multirow{2}{*}{ Item } & \multirow{2}{*}{ Control } & $\mathrm{AS}_{50 \%}$ & $\mathrm{AS}_{100 \%}$ \\
\cline { 3 - 4 } & & 1.17 & 1.17 \\
\hline Number services per conception & 1.17 & $83.33(5 / 6)$ & $83.33(5 / 6)$ \\
Conception rate, $\%$ & $83.33(5 / 6)$ & $83.33(5 / 6)$ & $83.33(5 / 6)$ \\
Fertility rate, $\%$ & $66.66(4 / 6)$ & $83.33(5 / 6)$ & $83.33(5 / 8)$ \\
lambing rate, $\%$ & $66.66(4 / 6)$ & 1.0 & 1.0 \\
litter size & 1.0 & 0 & 0 \\
Abortion rate, $\%$ & 20 & 0 \\
\hline
\end{tabular}

Effects of partial and total replacement of clover hay by acacia leaves on blood biochemical parameters in pregnant ewes are shown in Table (5). There were no significant changes in all serum biochemical parameters during premating period between control and treated animals. However, BUN declined $(\mathrm{P}<0.05)$ by $23 \%$ in the $100 \%$ acacia-treated ewes compared to control. While during pregnancy, serum total protein, globulin, glucose, and BUN concentrations significantly decreased $(\mathrm{P}<0.05)$ by the increase of acacia leaves compared to the control. Contrariwise, results revealed that partial and total replacements exhibited higher $(P<0.05)$ concentration of serum albumin than the control. Serum cholesterol and creatinine were not affected during either stage by the inclusion of acacia leaves.

Data of the effects of partial and total acacia replacement on BUN concentration at $\mathrm{PGF}_{2 \alpha}$ injection and estrus and at 5, 10 and 15 days post estrus are presented in Table (6). The BUN was reduced $(\mathrm{P}<0.05)$ at day 10 after estrus, while there were no changes $(\mathrm{P}>0.05)$ in $\mathrm{BUN}$ concentrations at $\mathrm{PGF}_{2 \alpha}$ injection, estrus, 5 and 15 days after estrus due to partial and total replacement by acacia leaves.

Table.6: Effect of partial and total replacement of clover hay by acacia leaves on blood urea nitrogen (BUN) concentrations $(\mathrm{mg} / \mathrm{dl})$ at $P G F_{2 \alpha}$ injection and estrus and at days 5, 10 and 20 post estrus in ewes

\begin{tabular}{|lcccc|}
\hline \multirow{2}{*}{ Item } & \multirow{2}{*}{ Control } & \multicolumn{3}{c|}{ Acacia } \\
\cline { 3 - 5 } & & $\mathrm{AS}_{50 \%}$ & $\mathrm{AS}_{100 \%}$ & $P$ value \\
\hline Day of $\mathrm{PGF}_{2 \alpha}$ injection & $21.08 \pm 1.1$ & $23.58 \pm 1.1$ & $23.82 \pm 1.1$ & 0.1895 \\
Day of heat & $19.25 \pm 1.68$ & $18.80 \pm 1.68$ & $15.56 \pm 1.84$ & 0.3107 \\
Day 5 after heat & $20.80 \pm 1.52$ & $20.75 \pm 1.39$ & $17.03 \pm 1.39$ & 0.1317 \\
Day 10 after heat & $20.20 \pm 1.59^{\mathrm{a}}$ & $22.45 \pm 1.45^{\mathrm{a}}$ & $15.48 \pm 1.59^{\mathrm{b}}$ & 0.0199 \\
Day 20 after heat & $21.22 \pm 1.79$ & $22.48 \pm 1.79$ & $22.00 \pm 1.79$ & 0.8822 \\
\hline
\end{tabular}

Means in the same row with different superscripts significantly differ $(P<0.05)$.

Table 7 illustrates effects of partial and total replacement of clover hay by acacia leaves on progesterone concentration at $\mathrm{PGF}_{2 \alpha}$ injection, estrus, 5, 10 and 20 days after estrus. Results indicated that there were no significant differences $(\mathrm{P}>0.05)$ among groups. Typically, progesterone profile exhibited minimum values at the onset of heat and started to increase by time thereafter.

Table.7: Effect of partial and total replacement of clover hay by acacia leaves on progesterone concentration ( $\mathrm{ng} / \mathrm{ml})$ in Barky ewes

\begin{tabular}{|c|c|c|c|c|}
\hline \multirow{2}{*}{ Item } & \multirow{2}{*}{ Control } & \multicolumn{2}{|c|}{ Acacia } & \multirow{2}{*}{$P$ value } \\
\hline & & $\mathrm{AS}_{50 \%}$ & $\mathrm{AS}_{100 \%}$ & \\
\hline Day of $\mathrm{PGF}_{2 \alpha}$ injection & $4.90 \pm 0.68$ & $3.90 \pm 0.68$ & $4.60 \pm 0.68$ & 0.5785 \\
\hline Day of heat & $1.28 \pm 0.56$ & $1.97 \pm 0.65$ & $1.03 \pm 0.56$ & 0.5598 \\
\hline Day 5 after heat & $2.16 \pm 0.57$ & $1.90 \pm 0.57$ & $2.60 \pm 0.57$ & 0.6888 \\
\hline Day 10 after heat & $4.50 \pm 0.29$ & $4.38 \pm 0.29$ & $4.74 \pm 0.32$ & 0.7094 \\
\hline Day 20 after heat & $5.78 \pm 0.69$ & $4.10 \pm 0.69$ & $5.68 \pm 0.62$ & 0.1959 \\
\hline
\end{tabular}

Means in the same row with different superscripts significantly differ $(P<0.05)$.

AS: Acacia saligna 
Effects of partial and total replacement of clover hay by acacia leaves on milk yield, milk composition and milk urea nitrogen (MUN) in lactating ewes are presented in Table 8. The results revealed that there is a linear reduction in DMI with increasing proportions of acacia leaves in ewe's diets. The $\mathrm{AS}_{50 \%}$ group produced higher $(P<0.05)$ milk yield than control and $\mathrm{AS}_{100 \%}$. The improvement due to partial substitution of acacia leaves was $11.8 \%$, while the total substitution of acacia leaves decreased milk yield by $15.3 \%$ compared to the control. Both $\mathrm{AS}_{50 \%}$ and $\mathrm{AS}_{100 \%}$ decreased $(P<0.05)$ milk fat percentage compared to control, while milk protein, lactose, SNF and MUN were not affected $(\mathrm{P}>0.10)$ by acacia replacement compared to control.

Table.8: Effect of partial and total replacement of clover hay by acacia leaves on Dry matter intake, milk yield, milk composition and milk urea N (MUN) in lactating Barky ewes

\begin{tabular}{|lcccccc|}
\hline \multirow{2}{*}{ Item } & \multirow{2}{*}{ Control } & \multicolumn{2}{c}{ Acacia } & \multicolumn{3}{c|}{$P$ value } \\
\cline { 3 - 7 } & & $\mathrm{AS}_{50 \%}$ & $\mathrm{AS}_{100 \%}$ & Treatment & Week & $\mathrm{T} \times \mathrm{W}$ \\
\hline DMI g/d & 1750 & 1685 & 1620 & - & - & - \\
Milk yield g/d & $509.9 \pm 22.0^{\mathrm{b}}$ & $570.1 \pm 19.7^{\mathrm{a}}$ & $431.7 \pm 22.0^{\mathrm{c}}$ & $<0.0001$ & $<0.0001$ & 0.9893 \\
Fat \% & $5.47 \pm 0.22^{\mathrm{a}}$ & $4.77 \pm 0.19^{\mathrm{b}}$ & $4.46 \pm 0.22^{\mathrm{b}}$ & 0.0033 & $<0.0001$ & 0.7655 \\
Protein \% & $3.88 \pm 0.07$ & $3.85 \pm 0.06$ & $4.01 \pm 0.07$ & 0.2269 & 0.2671 & 0.1262 \\
SNF \% & $10.70 \pm 0.19$ & $10.71 \pm 0.18$ & $11.06 \pm 0.19$ & 0.3673 & 0.2772 & 0.1397 \\
Lactose \% & $5.83 \pm 0.10$ & $5.81 \pm 0.10$ & $6.02 \pm 0.10$ & 0.2907 & 0.3160 & 0.1106 \\
MUN mg/dl & $20.19 \pm 0.95$ & $18.50 \pm 0.82$ & $19.07 \pm 0.93$ & 0.3768 & 0.1999 & 0.8854 \\
\hline
\end{tabular}

Means in the same row with different superscripts significantly differ $(P<0.05)$.

DMI: Dry Matter Intake, SNF: Solid Not Fat, MUN: Milk Urea Nitrogen.

Data of the effects of partial and total replacement of clover hay by acacia leaves on blood biochemical parameters in the lactating Barky ewes are shown in Table 9. Serum total protein and globulins concentrations declined $(P<0.05)$ due to partial substitution of acacia leaves $\left(\mathrm{AS}_{50 \%}\right)$ but not in the $\mathrm{AS}_{100 \%}$ ewes compared to the control. There were no significant differences on serum albumin, glucose and creatinine concentrations due to the acacia leaves substitution at either level. Contrariwise, serum cholesterol concentration was higher $(P<0.05)$ in the $\mathrm{AS}_{100 \%}$ than in $\mathrm{C}$ and $\mathrm{AS}_{50 \%}$ ewes. BUN concentrations were similar in $\mathrm{C}$ and $\mathrm{AS}_{50 \%}$ (23.87 vs. $22.59 \mathrm{mg} / \mathrm{dl})$ being greater $(P<0.05)$ than that in $\mathrm{AS}_{100 \%}$ $(20.39 \mathrm{mg} / \mathrm{dl})$ ewes.

Table.9: Effect of partial and total replacement of clover hay by acacia leaves on blood biochemical parameters in lactating Barky ewes

\begin{tabular}{|lcccccc|}
\hline Item & \multicolumn{3}{c}{ Acacia } & \multicolumn{3}{c|}{$P$ value } \\
\cline { 2 - 7 } & Control & $\mathrm{AS}_{50 \%}$ & $\mathrm{AS}_{100 \%}$ & $\mathrm{G}$ & $\mathrm{T}$ & $\mathrm{T} \times \mathrm{G}$ \\
\hline Total protein, $(\mathrm{g} / \mathrm{dl})$ & $6.69 \pm 0.18^{\mathrm{a}}$ & $5.95 \pm 0.16^{\mathrm{b}}$ & $6.39 \pm 0.18^{\mathrm{ab}}$ & 0.013 & 0.031 & 0.938 \\
Albumin $(\mathrm{g} / \mathrm{dl})$ & $4.10 \pm 0.07$ & $3.95 \pm 0.07$ & $4.01 \pm 0.07$ & 0.298 & $<0.0001$ & 0.443 \\
Globulin $(\mathrm{g} / \mathrm{dl})$ & $2.59 \pm 0.17^{\mathrm{a}}$ & $1.99 \pm 0.16^{\mathrm{b}}$ & $2.38 \pm 0.17^{\mathrm{ab}}$ & 0.043 & 0.002 & 0.985 \\
Glucose $(\mathrm{mg} / \mathrm{dl})$ & $45.87 \pm 1.76$ & $44.35 \pm 1.64$ & $42.17 \pm 1.88$ & 0.300 & $<0.0001$ & 0.0100 \\
Creatinine $(\mathrm{mg} / \mathrm{dl})$ & $0.99 \pm 0.05$ & $1.03 \pm 0.04$ & $1.01 \pm 0.05$ & 0.830 & 0.051 & 0.275 \\
Cholesterol $(\mathrm{mg} / \mathrm{dl})$ & $63.19 \pm 2.47^{\mathrm{ab}}$ & $56.67 \pm 2.30^{\mathrm{b}}$ & $66.16 \pm 2.47^{\mathrm{a}}$ & 0.029 & 0.011 & 0.006 \\
BUN $(\mathrm{mg} / \mathrm{dl})$ & $23.87 \pm 0.81^{\mathrm{a}}$ & $22.59 \pm 0.73^{\mathrm{a}}$ & $20.39 \pm 0.79^{\mathrm{b}}$ & 0.014 & $<0.0001$ & 0.089 \\
\hline
\end{tabular}

Means in the same row with different superscripts significantly differ $(P<0.05)$.

AS: Acacia saligna; BUN: Blood Urea Nitrogen

Table 10 presents data of the effects of acacia replacement on birth weight, weaning weight and average daily gain of Barky lambs born of treated ewes. The highest birth weight was found in control-ewe's lambs $(3.85 \mathrm{~kg})$ which was comparable to those lambs born of $\mathrm{AS}_{50 \%}\left(3.09 \mathrm{~kg}\right.$ ) ewes. However, $\mathrm{AS}_{100 \%}$ ewe's lambs recorded the lowest $(\mathrm{P}<0.05)$ birth weight $(2.97 \mathrm{~kg})$.
Similar trend was found with weaning weight as the lowest weaning weight was found on lambs born of $\mathrm{AS}_{100 \%}$ ewes $(15.59 \mathrm{~kg}$ ) representing $22.7 \%$ weight loss, however $\mathrm{AS}_{50 \%}$ - ewe's lambs had less weaning weight by $14.7 \%$ compared to C-ewe's lambs. Although the partial replacement of acacia leaves decreased the weaning weight by $14.7 \%$ but the difference was not statistically 
significant. Average daily gain of lambs decreased by 13.6 and $22.7 \%$ in $\mathrm{AS}_{50 \%}$ and $\mathrm{AS}_{100 \%}$, respectively, with

non-significant difference between $\mathrm{C}$ and $\mathrm{AS}_{50 \%}$.

Table.10: Effect of partial and total replacement of clover hay by acacia leaves on birth weight, weaning weight and average daily gain (ADG) of Barky lambs

\begin{tabular}{|lcccc|}
\hline \multirow{2}{*}{ Item } & \multirow{2}{*}{ Control } & \multicolumn{3}{c|}{ Acacia } \\
\cline { 3 - 5 } & & $\mathrm{AS}_{50 \%}$ & $\mathrm{AS}_{100 \%}$ & P value \\
\hline Birth weight, $\mathrm{kg}$ & $3.85 \pm 0.26^{\mathrm{a}}$ & $3.09 \pm 0.20^{\mathrm{ab}}$ & $2.97 \pm 0.26^{\mathrm{b}}$ & 0.043 \\
Weaning weight, $\mathrm{kg}$ & $20.17 \pm 1.21^{\mathrm{a}}$ & $17.20 \pm 0.94^{\mathrm{ab}}$ & $15.59 \pm 1.21^{\mathrm{b}}$ & 0.033 \\
ADG, g/d & $145.77 \pm 9.19^{\mathrm{a}}$ & $125.92 \pm 7.12^{\mathrm{ab}}$ & $112.67 \pm 9.19^{\mathrm{b}}$ & 0.042 \\
\hline
\end{tabular}

Means in the same row with different superscripts significantly differ $(P<0.05)$.

ADG: Average Daily Gain. Means in the same row with different superscripts significantly differ $(P<0.05)$.

\section{DISCUSSION}

\section{Feed intake and digestion}

The reduction in DMI of sheep due to partial or total substitution of clover hay by acacia leaves hay might be due to astringency, decreased palatability, which possibly resulting in feeds avoidance and adverse effects on digestion as reported previously $[12,15]$. Moreover, Waghorn et al. [16] demonstrated that decreased ruminal turnover and rate of digestion were more important than palatability in reducing intake of sheep fed diets containing high levels of CT. Other researchers suggested that high concentrations of tannins could reduce the intake in the following ways: (1) physical distension of the rumen, resulting in a decrease in dry matter digestion; (2) hormonal response due to the binding of tannins to the gut wall; (3) reduction of the diet palatability caused by its astringency; and/or (4) binding of tannins to salivary and mucosal proteins $[\mathbf{1 7}, \mathbf{1 8}]$.

The depression in apparent total tract digestibility of CP associated with replacement of clover hay by acacia leaves might have been due to the formation of complexes between tannins and dietary proteins and carbohydrates [19], as well as reducing rumen microbial proteolytic, ureolytic and cellulolytic enzyme activities, general fermentative activities and cell multiplication [20]. Tannins might also interfere with digestion by binding microbial enzymes and this might explain why acaciagiven animals in this study decreased apparent total tract digestibility of cell walls digestion [21]. Animals given acacia in the current study tended to decrease $\mathrm{N}$ balance [22]. This is probably due to the presence of CT, high proportion of acid detergent insoluble nitrogen and high urinary $\mathrm{N}$, which in turn was possibly attributed to an imbalance of high $\mathrm{N}$ relative to a low energy in the rumen. The interaction of tannins with protein alters the partitioning of $\mathrm{N}$ within the sheep guts, shifting the route of excretion away from urine toward feces [3, 23]. This reduction in urinary $\mathrm{N}$ reduces volatile $\mathrm{N}$ losses after land application with dairy manure, which in turn reduces environmental losses through nitrate leaching, $\mathrm{NH}_{3}$ volatilization and nitrous oxide emissions [24]. Confirming these effects of CT-containing forages, Powell et al. reported that the ratio of $\mathrm{N}$ excreted in feces and urine was highest for low-tannin and high-tannin birds' foot trefoil treatment and lowest for the alfalfa treatment [25]. Current study data revealed that the higher fecal $\mathrm{N}$ excretion in the presence of active tannins was matched by lower urinary $\mathrm{N}$ excretion. This shift can be explained by the lower rumen degradability of nitrogenous compounds and is confirmed by effects of CT on rumen fluid ammonia and total $\mathrm{N}$ as previously stated $[26,27]$. Volatile fatty acids production was not affected by acacia leaves replacement. The possible explanation for this might be due to lack of effect of supplemented tannins on rumen bacteria or to the adaptation of rumen microorganisms to tannins [28].

\section{Reproductive performance}

Conception rate was similar among treatments; however fertility and lambing rates were higher by about $25 \%$ when acacia leaves were replaced in ewe's diets. These effects probably occur as a result of including tannins-rich plants in ewe's diets, which enhance the live body weight, body condition, and energy and protein intake and protein absorption from the small intestine [29]. Moreover, increased plasma of essential amino acids principally branched chain amino acids and plasma metabolic hormones especially insulin were found in tannin-fed animals [30]. Short periods of improved nutrient supply before and during mating and reproduction have been known to affect ovulation rate along with increased size and number of follicle [31], reduce follicular atresia [32], altered plasma gonadotrophin concentration [33] and affect ovarian sensitivity to gonadotrophins [32]. A large part of the dietary protein is hydrolyzed in the rumen to ammonia, some of which is re-incorporated into microbial protein. Excess ammonia is absorbed from the rumen and metabolized to urea in the liver, leading to increased plasma and uterine ammonia and urea concentrations [29] which may increase the number of early embryonic losses [34]. In agreement with the present finding, subsequent 
grazing experiments with sheep showed that CT in $L$. corniculatus increased both ovulation rate and lambing percentage by $20-27 \%$ [29]. The improvement of the conception rate in the current study might be ascribed to that BUN level was less than $20 \mathrm{mg} / \mathrm{dL}$ at the insemination day. The results of the BUN is confirmed by Butler who indicated that conception rate decreased when serum urea nitrogen concentrations exceeded $20 \mathrm{mg} / \mathrm{dL}$ on the day of insemination and suggested that degradation of excessive amounts of dietary protein in the rumen contributed to infertility [35].

\section{Milk production and composition}

Effects of tannins-rich feeds on milk fat and protein composition varies markedly depending on the concentration of tannins present in the feeds. Condensed tannins in high concentrations (e.g. total replacement by acacia) generally have adverse effects on animal performance, while moderate concentrations (e.g. partial replacement by acacia) might have positive effects. The negative effects of tannin-diets on milk yield and fat content might be due the reduction of feed intake, decreased rate of digestion and development of conditioned aversion [36, 37]. Wang et al. reported that tannins from Lotus corniculatus, which contained moderate amounts of CT (44.5 g/kg DM), fed to lactating ewes increased milk yield, lactose and protein content and decreased milk fat as found in the present study[38]. One reason for these effects could be an increase in metabolizable protein supply from the protein binding action of CT because effects of tannins on ruminant productivity depend on the quality and quantity of dietary protein [28]. Protein protection by tannins from microbial degradation in the rumen resulted in an increase of milk production in dairy cows [39], dairy goats [40] and sheep [41]. Contrariwise, reported no improvement in ewe's milk yield when acacia leaves were supplemented into their diets at 100 or $200 \mathrm{~g} /$ day [42].

Parallel to our finding, Maamouri et al. indicated that milk protein content hasn't been affected significantly in acacia-treated ewes [42]. On the contrary, these results disagree with those of Wang et al. for dairy sheep [38] and Woodward et al. (1999) for dairy cows [39] who found increased milk protein content when tannin was supplemented to the diet. The CT-containing plants can protect dietary protein against degradation in the rumen and increase $\mathrm{N}$ utilization, resulting in a reduction in MUN concentration and nitrogenous waste excretion and improved nutritional status of the animal. However, Ben Salem et al. found that supplementing lambs fed on spineless cactus pads with small amount (i.e. $100 \mathrm{~g} /$ day) of air-dried acacia and $200 \mathrm{~g}$ soybean meal significantly increased their growth rate compared to those receiving the same diet but without acacia leaves (102 g/day versus
$75 \mathrm{~g} /$ day) [44]. When the level of acacia was doubled, the beneficial effect of acacia disappeared since the average daily gain of lambs was $82 \mathrm{~g} /$ day. These findings raised the question as to whether the positive effect of $100 \mathrm{~g}$ acacia is because of the interaction between acacia tannins and soybean meal protein.

\section{Blood metabolites}

Plant secondary compounds may affect blood parameters by maintaining them [45], while others may decrease [46] or increase [47] plasma glucose concentration, or alter serum insulin concentration [48]. In agreement with our finding, Waghorn et al. and Ben Salem et al. reported that BUN was lower when sheep and goats were fed legumes that contained tannins [44, 49]. However, reduced proteolysis in ewes receiving Acacia cyanophylla with concentrate could have been caused by effects of acacia tannins on microbial proteolytic activity [50]. Additionally, others demonstrated that that BUN was also higher in the Bermuda grass hay-based ration compared with the Lespedeza cuneata forage (23.1 $\mathrm{mg}$ CT/mg soluble protein) in goats $[\mathbf{5 1}, \mathbf{5 2}]$.

Solaiman et al. reported that BUN, albumin, creatinine, triglycerides and glucose were unaffected in the diets of goats consuming different levels of the CT containing forage of sericea lespedeza (Lespedeza cuneata) [53], however our data indicated elevation $(\mathrm{P}<0.05)$ of serum albumin due to partial substitution of clover hay by acacia leaves, while total substitution decreased $(\mathrm{P}<0.05)$ serum albumin. It is well known that serum albumin is a bioindicator of the nutritional status of the animal and it decreases when animals are diseased. The glucose values ranged from 61.2 to $65.6 \mathrm{mg} / \mathrm{dL}$ in the current study, which were similar to previous studies $[\mathbf{5 1}, \mathbf{5 3}]$.

Silanikove et al. demonstrated that the blood metabolic profile was examined in non-lactating and non-pregnant goats consuming Quercus calliprinos (oak), Pistacia lentiscus (pistacia) and Cerafonia siliqua (carob) leaves [54]. Overall view of the data of this study revealed that the controversy in the literature with the current study implying the ability of tannins to modulate the rumen fermentation, nutrients utilization and performance efficiency of ruminants is probably due to the great diversity in the structural features, ruminants species, and consequently in the reactivity of these plant secondary compounds. The dose-dependent effect of tannins and proportions of rumen degradable protein are another major issues because of the difficulty in selecting concentrations to positively affect a particular parameter without conferring a negative response on others (e.g., in overall diet utilization). 


\section{CONCLUSION}

Partial (up to $50 \%$ of the forage) replacement of clover hay by acacia leaves could be implemented in sheep feeding without detrimental effects on the utilization of nutrients, fermentation characteristics, reproductive and productive performance.

\section{ACKNOWLEDGMENTS}

The authors express their sincere gratitude to the farm crew for their endless help.

\section{CONFLICT OF INTEREST}

The authors declare that they have no competing interests.

\section{REFERENCES}

[1] Makkar, H.P.S. (2005). Use of nuclear and related techniques to develop simple tannin assays for predicting and improving the safety and efficiency of feeding ruminants on tanniniferous tree foliage: Achievements, result implications, and future research. Anim. Feed Sci. Technol. 122, 3-12.

[2] Wang, Y., Berg, B.P., Barbieri, L.R., Veira, D.M., McAllister, T.A. (2006). Comparison of alfalfa and mixed alfalfa-sainfoin pastures for grazing cattle: Effects on incidence of bloat, ruminal fermentation, and feed intake. Can. J. Anim. Sci. 86, 383-392.

[3] Waghorn, G.C. (2008). Beneficial and detrimental effects of dietary condensed tannins for sustainable sheep and goat production-Progress and challenges. Anim. Feed Sci. Technol. 147, 116-139.

[4] Kumara Mahipala, M.B.P., Krebs, G.L., McCafferty, P., Gunaratne, L.H.P. (2009). Chemical composition, biological effects of tannin and in vitro nutritive value of selected browse species grown in the West Australian Mediterranean environment. Anim. Feed Sci. Technol. 153, 203215.

[5] Bunglavan, S.J., Dutta, N. (2013). Use of tannins as organic protectants of proteins in digestion of ruminants. J. Livest. Sci. 4, 67-77.

[6] NRC (2007). Nutrient Requirements of Domestic Animals: nutrient requirements of sheep. National Academy of Science, Washington, DC.

[7] AOAC (2006). Official Methods of Analysis, Arlington, VA, USA.

[8] Williams, J., Anderson, D.C., Kress, D.D. (1979). Milk production in Herford cattle. I. Effects of separation internal on weigh-suckle weigh milk production estimates. J. Anim. Sci. 49, 1438-1442.

[9] Van Soest, P.J., Robertson, J.B., Lewis, B.A. (1991). Methods for dietary fiber, neutral detergent fiber and nonstarch polysaccharides in relation to animal nutrition. J. Dairy Sci. 74, 3583-3597.
[10]Preston, T.R. (1995). Biological and chemical analytical methods. In: T.R. Preston (Ed.) Tropical Animal Feeding: A Manual for Research Workers. FAO, Rome, pp:191-264 (Chap. 9).

[11] Warner, A.C.I. (1964). Production of volatile fatty acids in the rumen. Methods of measurements. Nutr. Abs. Rev. 34, 339.

[12] Makkar, H.P.S. (2003). Effects and fate of tannins in ruminant animals, adaptation to tannins, and strategies to overcome detrimental effects of feeding tannin-rich feeds. Small Rum. Res. 49, 241-256.

[13] Makkar, H.P.S., Blummel, M., Borowy, N.K., Becker, K. (1993). Gravimetric determination of tannins and their correlations with chemical and protein precipitation methods. J. Sci. Food Agric. 61, 161-165.

[14]SAS (2002). Statistical Analysis System, Version 9.1. SAS Institute, Cary, NC, USA.

[15]Hervás, G., Frutos, P., Giráldez, F.J., Mantecón, A.R., Álvarez del Pino, M.C. (2003). Effect of different doses of quebracho tannins extract on rumen fermentation in ewes. Anim. Feed Sci. Technol. 109, 65-78.

[16] Waghorn, G.C., Shelton, I.D., McNabb, W.C., McCutcheon, S.N. (1994a). Effects of condensed tannins in Lotus pedunculatus on its nutritive value for sheep. 2. Nitrogenous aspects. J. Agric. Sci. (Camb.) 123, 109-119.

[17] Kumar, R., Vaithiyanathas, S. (1990). Occurrence, nutritional significance and effect on animal productivity of tannins in tree leaves. Anim. Feed Sci. Technol. 30, 21-38.

[18] Mueller-Harvey, I. (2006). Unraveling the conundrum of tannins in animal nutrition and health. J. Sci. Food Agric. 86, 2010-2037.

[19] Makkar, H.P.S., Singh, B., Dawra, R.K. (1988) Effect of tannin-rich oak (Quercus incana) on various microbial enzyme activities of the bovine rumen. Brit. J. Nutr. 60, 287-296.

[20] Muhammed, S., Stewart, C.S., Acamovic, T. (1994) Effects of tannic acid on cellulose degradation, adhesion and enzymatic activity of rumen microorganisms. Proc. Soc. Nutr. Physiol. 3, 25-30.

[21] McSweeney, C.S., Palmer, B., McNeill, D.M., Krause, D.O. (2001). Microbial interactions with tannins nutritional consequences for ruminants. Anim. Feed Sci. Technol. 91, 83-93.

[22]Degen, A.A., Blanke, A., Becker, K., Kaman, M., Benjamin, R.W., Makkar, H.P.S. (1997). The nutritive value of Acacia saligna and Acacia Salicinea for goats and sheep. J. Anim. Sci. 64, 253259. 
[23] Beauchemin, K.A., Kreuzer, M., O'Mara, F., McAllister, T.A. (2008). Nutritional management for enteric methane abatement: a review. Aust. J. Exp. Agric. 48, 21-27.

[24] Misselbrook, T.H., Powell, J.M., Broderick, G.A., Grabber, J.H. (2005). Dietary manipulation in dairy cattle: Laboratory experiments to assess the influence on ammonia emissions. J. Dairy Sci. 88, 1765-1777.

[25] Powell, J.M., Broderick, G.A., Grabber, J.H. and Hymes-Fecht, U.C. (2009) Technical note: Effects of forage protein-binding polyphenols on chemistry of dairy excreta. J. Dairy Sci. 92, 1765-1769.

[26] Scharenberg, A., Arrigo, Y., Gutzwiller, A., Soliva, C.R., Wyss, U. Kreuzer, M., Dohme, F. (2007). Palatability in sheep and in vitro nutritional value of dried and ensiled sainfoin (Onobrychis viciifolia) birdsfoot trefoil (Lotus corniculatus), and chicory (Cichorium intybus). Arch. Anim. Nutr. 61, 481496.

[27] Theodoridou, K., Aufrère, J., Andueza, D., Pourrat, J., Le Morvan, A., Stringano, E., Mueller-Harvey, I., Baumont, R. (2010). Effects of condensed tannins in fresh sainfoin (Onobrychis viciifolia) on in vivo and in situ digestion in sheep. Anim. Feed Sci. Technol. 160, 23-38.

[28] Patra, A.K., Saxena, J. (2011). Exploitation of dietary tannins to improve rumen metabolism and ruminant nutrition. J. Sci. Food Agric. 91, 24-37.

[29] Min, B.R., Attwood, G.T., McNabb, W.C., Barry, T.N. (2001). Effect of condensed tannins on proteolytic bacterial populations in the rumen and on nitrogen flow to the abomasum of sheep. J. Anim. Sci. 79, 163 (Abstr.).

[30] Downing, J.A., Joss, J., Scaramuzzi, R.J. (1995). A mixture of the branched chain amino acids leucine, isoleucine and valine increases ovulation rate in ewes when infused during the late luteal phase of the estrus cycle: an effect that may be mediated by insulin. J. Endocrinol. 145, 315-323.

[31] Bellows, R.A., Pope, A.L., Meyer, R.K., Chapman, A.B., Casida, L.E. (1963). Physiological mechanisms in nutritionally induced differences in ovarian activity of mature ewes. J. Anim. Sci. 22, 93-108.

[32] Downing, J.A., Scaramuzzi, R.J. (1991). Nutrient effects on ovulation rate, ovarian function and the secretion of gonadotrophic and metabolic hormones. J. Reprod. Fert. 43, 209-227.

[33] Smith, J.F. (1988). Influence of nutrition on ovulation rate in the ewe. Aust. J. Biol. Sci. 41, 2736.
[34]El-Zarkouny, S.Z., Ghobashy, H., Nour El-Din, A.N.M., Abdel-Gauad, E.I., Hassan, G.A. (2007). Lambing and embryonic mortality rates in Awassi and Barky ewes and their crosses throughout three different mating seasons in the west coastal region of Egypt. Alex. J. Agric. Res. 52, 15-24.

[35]Butler, W.R. (1998). Review: Effect of protein nutrition on ovarian and uterine physiology in dairy cattle. J. Dairy Sci. 81, 2533-2539.

[36] Grainger, C., Clarke, T., Auldist, M.J., Beauchemin, K.A., McGinn, S.M., Waghorn, G.C. (2009). Potential use of Acacia mearnsii condensed tannins to reduce methane emissions and nitrogen excretion from grazing dairy cows. J. Anim. Sci. (Camb.) 89, 241-251.

[37] Molle, G., Decandia, M., Giovanetti, V., Cabiddu, A., Fois, N., Sitzia, M. (2009). Responses to condensed tannins of flowering sulla (Hedysarum coronarium L.) grazed by dairy sheep. Part 1: Effects on feeding behavior, intake, diet digestibility and performance. Livest. Sci. 123, 138-146.

[38] Wang, Y., Douglas, G.B., Waghorn, G.C., Barry, T.N., Foote, A.G. (1996). The effect of condensed tannins in Lotus corniculatus upon lactation performance in ewes. J. Agric. Sci. (Camb.) 126, 353-362.

[39] Woodward, S.L., Auidist, M.J., Laboyrie, P.J., Jansen, E.B.L. (1999). Effect of Lotus corniculatus and condensed tannin on milk yield and milk composition of dairy cows. Proc. N.Z. Soc. Anim. Prod. 59, 152-155.

[40] Rouissi, H., Atti, N., Mahouachi, M., Rekik, B. (2006). Effect de la complementation azotée sur les performances zootechniques de la chèvre locale. Trop. Culture. 24, 111-114.

[41] Penning, P.D., Orr, R. J., Treacher, T.T. (1988). Responses of lactating ewes offered fresh herbage indoors and when grazing to supplements containing differing protein concentrations. Anim. Prod. 46, 403-415.

[42] Maamouri, O., Atti, N., Kraiem, K., Mahouachi, M. (2011). Effects of concentrate and Acacia cyanophylla foliage supplementation on nitrogen balance and milk production of grazing ewes. Livest. Sci. 139, 264-270.

[43]Ben Salem, H., Atti, N., Priolo, A., Efzaoui, A. N. (2002). Polyethylene glycol in concentrate or feed blocks to deactivate condensed tannins in Acacia cyanophylla Lindl. Foliage. 1-Effects on intake, digestion and growth by Barbarine lambs. J. Anim. Sci. 75, 127-135.

[44] Ben Salem, H., Makkar, H.P.S., Nefzaoui, A., Hassayoun, L., Abidi, S. (2005). Benefit from the 
association of small amounts of tannin-rich shrub foliage (Acacia cyanophylla Lindl.) with soya bean meal given as supplements to Barbarine sheep fed on oaten hay. Anim. Feed Sci. Technol. 122, 173186.

[45] Raghuvansi, S. K., Prasad, R., Mishra, A.S., Chaturvedi, O.H., Tripathi, M.K., Misra, A.K., Saraswat, B.L., Jakhmola, R.C. (2007). Effect of inclusion of tree leaves in feed on nutrient utilization and rumen fermentation in sheep. Bioresour. Technol. 98, 511-517.

[46] Joy, P.P., Thomas, J., Mathew, S., Skaria, B.P. (2001). Medicinal plants. In: Bose, T.K., Kabir, J., Das, P., Joy, P.P. (Eds.), Tropical Horticulture. Naya Prokash, Calcutta, India, pp. 449-632.

[47] Mohammed, N., Ajisaka, N., Lila, Z.A., Hara, K., Mikuni, K., Kanda, S. Itabashi, H. (2004). Effect of Japanese horseradish oil on methane production and ruminal fermentation in vitro and in steers. J. Anim. Sci. 82, 1839-1846.

[48] Devant, M., Anglada, A., Bach, A. (2007). Effects of plant extract supplementation on rumen fermentation and metabolism in young Holstein bulls consuming high levels of concentrate. Anim. Feed Sci. Technol. 137, 46-57.

[49] Waghorn, G.C., Shelton, I.D., McNabb, W.C. (1994b). Effects of condensed tannins in Lotus pedunculatus on its nutritive value for sheep. 1. Non-nitrogenous aspects. J. Agric. Sci. 123, 99-107.

[50] Jones, G.A., Jakober, K.D., Bae, H.D., McAllister, T.A., Cheng, K.J. (1993). Some interactions between condensed tannins of forage legumes, bovine serum albumin and five strains of proteolytic rumen bacteria. Proceedings of the World Conference on Animal Production, Edmonton, Canada 36, 68-69.

[51] Turner, K.E., Wildeus, S., Collins, J.R. (2005). Intake, performance, and blood parameters in young goats offered high forage diets of lespedeza or alfalfa hay. Small Rum. Res. 59, 15-23.

[52] Moore, D.A., Terrill, T.H., Kouakou, B., Shaik, S.A., Mosjidis, J.A., Miller, J.E., Vanguru, M. Kannan, G., Burke, J.M. (2008). The effects of feeding Sericea lespedeza hay on growth rate of goats naturally infected with gastrointestinal nematodes. J. Anim. Sci. 86, 2328-2337.

[53] Solaiman, S., Thomas, J., Dupre, Y., Min, B.R., Gurung, N., Terrill, T.H., Haenlein, G.F.W. (2010). Effect of feeding sericea lespedeza (Lespedeza cuneata) on growth performance, blood metabolites, and carcass characteristics of Kiko crossbred male kids. Small Rum. Res. 93, 149-156.

[54] Silanikove, N., Gilboa, N., Perevolotsky, A., Nitsan, Z. (1996). Goats fed tannin-containing leaves do not exhibit toxic syndromes. Small Rum. Res. 21, 195201.

Table.5: Effect of partial and total replacement of clover hay by acacia leaves on blood biochemical parameters in the premating and pregnant Barky ewe-lambs

\begin{tabular}{|c|c|c|c|c|c|c|c|c|c|}
\hline Item & \multicolumn{3}{|c|}{ Premating period } & \multicolumn{3}{|c|}{ Pregnancy period } & \multicolumn{3}{|c|}{$P$ value } \\
\hline & Control & $\mathrm{AS}_{50 \%}$ & $\mathrm{AS}_{100 \%}$ & Control & $\mathrm{AS}_{50 \%}$ & $\mathrm{AS}_{100 \%}$ & $\bar{G}$ & $\mathrm{~T}$ & $\mathrm{~T} \times \mathrm{G}$ \\
\hline $\begin{array}{l}\text { Total protein } \\
(\mathrm{g} / \mathrm{dl})\end{array}$ & $8.56 \pm 0.32$ & $8.29 \pm 0.34$ & $8.23 \pm 0.32$ & $\begin{array}{c}7.70 \pm 0.16 \\
\text { A }\end{array}$ & $\begin{array}{r}7.13 \pm 0.16 \\
\text { B }\end{array}$ & $\begin{array}{r}6.97 \pm 0.18 \\
\text { B }\end{array}$ & 0.000 & 0.004 & 0.509 \\
\hline $\begin{array}{l}\text { Albumin } \\
(\mathrm{g} / \mathrm{dl})\end{array}$ & $4.08 \pm 0.13$ & $4.25 \pm 0.14$ & $4.12 \pm 0.13$ & $\begin{array}{c}4.32 \pm 0.05 \\
\text { B }\end{array}$ & $\begin{array}{r}4.58 \pm 0.05 \\
\mathrm{~A}\end{array}$ & $\begin{array}{r}4.43 \pm 0.05 \\
\mathrm{~A}\end{array}$ & 0.002 & 0.002 & 0.001 \\
\hline $\begin{array}{c}\text { Globulin(g/d } \\
1)\end{array}$ & $4.50 \pm 0.34$ & $4.05 \pm 0.35$ & $4.12 \pm 0.34$ & $\begin{array}{c}3.38 \pm 0.17 \\
\text { A }\end{array}$ & $\begin{array}{r}2.54 \pm 0.17 \\
\text { B }\end{array}$ & $\begin{array}{r}2.56 \pm 0.19 \\
\text { B }\end{array}$ & $\begin{array}{c}0.000 \\
6\end{array}$ & $<0.001$ & 0.524 \\
\hline $\begin{array}{r}\text { Glucose (mg/ } \\
\mathrm{dl})\end{array}$ & $\begin{array}{c}55.59 \pm 4.1 \\
5\end{array}$ & $\begin{array}{c}61.96 \pm 4.3 \\
5\end{array}$ & $\begin{array}{c}61.38 \pm 4.1 \\
5\end{array}$ & $\begin{array}{c}68.91 \pm 2.8 \\
6^{\mathrm{A}}\end{array}$ & $\begin{array}{c}57.01 \pm 2.8 \\
6^{\mathrm{B}}\end{array}$ & $\begin{array}{c}62.45 \pm 3.3 \\
2^{\mathrm{B}}\end{array}$ & 0.020 & 0.001 & 0.089 \\
\hline $\begin{array}{l}\text { Creatinine } \\
(\mathrm{mg} / \mathrm{dl})\end{array}$ & $0.98 \pm 0.06$ & $0.89 \pm 0.06$ & $1.03 \pm 0.6$ & $1.03 \pm 0.04$ & $0.99 \pm 0.04$ & $0.96 \pm 0.05$ & 0.604 & 0.001 & 0.311 \\
\hline $\begin{array}{l}\text { Cholesterol } \\
(\mathrm{mg} / \mathrm{dl})\end{array}$ & $\begin{array}{c}34.93 \pm 2.5 \\
7 \\
\end{array}$ & $\begin{array}{c}37.03 \pm 2.6 \\
9 \\
\end{array}$ & $\begin{array}{c}41.61 \pm 2.5 \\
7 \\
\end{array}$ & $\begin{array}{c}47.81 \pm 1.7 \\
7 \\
\end{array}$ & $\begin{array}{c}47.12 \pm 1.7 \\
7 \\
\end{array}$ & $\begin{array}{c}48.36 \pm 2.0 \\
5 \\
\end{array}$ & 0.937 & $<0.001$ & 0.032 \\
\hline $\begin{array}{l}\text { BUN } \\
(\mathrm{mg} / \mathrm{dl})\end{array}$ & $\begin{array}{c}26.10 \pm 1.3 \\
1^{\mathrm{A}}\end{array}$ & $\begin{array}{c}22.68 \pm 1.3 \\
8^{\mathrm{AB}}\end{array}$ & $\begin{array}{c}19.99 \pm 1.3 \\
1^{\mathrm{B}}\end{array}$ & $\begin{array}{c}20.69 \pm 0.6 \\
5^{\mathrm{A}}\end{array}$ & $\begin{array}{c}20.13 \pm 0.6 \\
5^{\mathrm{A}}\end{array}$ & $\begin{array}{c}13.13 \pm 0.7 \\
5^{\mathrm{B}}\end{array}$ & $\begin{array}{c}<0.00 \\
01\end{array}$ & $<0.001$ & 0.035 \\
\hline
\end{tabular}

AS: Acacia saligna; BUN: Blood Urea Nitrogen. 